\title{
KORELASI KUAT TEKAN TERHADAP KAPASITAS GESER BALOK BETON DENGAN VARIASI PERAWATAN
}

\author{
Elviana $^{1}$, Ashar Saputra ${ }^{2}$, Djoko Sulistyo \\ ${ }^{1}$ Pendidikan Teknik Sipil dan Perencanaan, Fakultas Teknik Universitas Negeri Yogyakarta \\ ${ }^{2}$ Departemen Teknik Sipil dan Lingkungan, Fakultas Teknik, Universitas Gadjah Mada, Yogyakarta \\ Email: margarethaelviana27@uny.ac.id
}

\begin{abstract}
The beam material in the construction world is designed to withstand collapse due to bending, diagonal drag, and sliding. Shear behavior in design becomes a very complex problem and is not easy to predict. However, failure due to the influence of shear forces is avoided in the design world due to damage that occurs without prior precautions, so that building users do not have the opportunity to save themselves. The study of variables that determine shear forces is a contradictory debate. One of the influential variables is the compressive strength of concrete (fc'). This work examines the correlation of compressive strength to the shear capacity of concrete beams with variations in care because there is still very little literature in Indonesia that studies the relationship of the two variables. Tests carried out on beams with reinforcement and without reinforcement which have pxIxt size is $1000 \times 200 \times 400 \mathrm{~mm}$ by getting the behavior of the point load at the center of the span (three-point load). Maintenance variations are carried out by testing in wet conditions as material representation in water construction and dry conditions for ordinary buildings. After 150 days of study, it was found that the compressive strength of concrete had a higher correlation with the strength of the concrete at the time of cracking $(\mathrm{Vcr})$ than the strength of ultimate concrete (Vu). Wet conditions will produce lower strength than linear conditions with linear correlation levels of both.
\end{abstract}

Keywords: concrete, compressive strength, shear strength, concrete treatment

\begin{abstract}
ABSTRAK
Material balok dalam dunia konstruksi dirancang untuk tahan terhadap keruntuhan akibat lentur, tarik diagonal, dan geser. Parilaku geser dalam perancangan menjadi permasalahan yang sangat kompleks dan tidak mudah untuk diprediksi. Namun demikian kegagalan karena pengaruh gaya geser sangat dihindari dalam dunia perancangan dikarenakan kerusakan yang terjadi tanpa didahului dengan peringatan terlebih dahulu, sehingga pengguna bangunan tidak memiliki kesempatan untuk menyelematkan diri. Pengkajian mengenai variabel yang menentukan kekuatan geser menjadi sebuah perdebatan yang kontradiktif. Salah satu variabel yang berpengaruh adalah kekuatan tekan beton $\left(f_{c}{ }^{\prime}\right)$. Penelitian ini mengkaji mengenai korelasi kuat tekan terhadap kapasitas geser balok beton dengan variasi perawatan dikarenakan masih sangat sedikit literatur di Indonesia yang melakukan pengkajian hubungan kedua variabel tersebut. Pengujian dilakukan pada balok dengan tulangan dan tanpa tulangan yang memiliki ukuran pxlxt adalah 1000x200x400 mm dengan mendapatkan perilaku beban titik di pusat bentang (threepoint load). Variasi perawatan dilakukan dengan melakukan pengujian pada kondisi basah sebagai representasi material pada konstruksi bangunan air dan kondisi kering untuk bangunan biasa. Setelah dilakukan pengkajian selama 150 hari diperoleh hasil bahwa kuat tekan beton memiliki korelasi lebih tinggi terhadap kekuatan beton pada saat retak $\left(V_{c r}\right)$ daripada kekuatan beton ultimit $\left(V_{u}\right)$. Kondisi basah akan menghasilkan kekuatan yang lebih rendah dari kondisi kering yang linier dengan tingkat korelasi keduanya.
\end{abstract}

Kata kunci: beton, kuat tekan, kuat geser, perawatan beton 


\section{PENDAHULUAN}

Karakteristik yang dimiliki beton menjadi salah satu alasan tingginya pemilihan penggunaan material tersebut dalam dunia infrastuktur. Kombinasi antara material beton dan tulangan baja menjadi satu konstruksi yang utuh merupakan salah satu perkembangan teknologi untuk menghasilkan struktur bangunan yang memiliki kekuatan yang tinggi. Balok beton bertulang dirancang untuk tahan terhadap beberapa kegagalan terhadap keruntuhan lentur, keruntuhan tarik diagonal, dan keruntuhan geser. Perilaku balok beton bertulang keruntuhan geser sangat berbeda dengan keruntuhan akibat lentur. Pada keruntuhan geser keruntuhan yang terjadi tidak ditandai dengan adanya peringatan terlebih dahulu. Peringatan dapat berupa retak maupun lendutan. Retak diagonal yang terjadi lebih lebar dari pada keruntuhan lentur. Pada keruntuhan ini, balok yang didesain nantinya akan bersifat getas (brittle), Nawy (2010). Keruntuhan geser sangat dihindari dalam merancang konstruksi dikarenakan tidak memberikan peluang bagi pengguna untuk menyelematkan diri.

Keruntuhan geser terjadi pada perbandingan $(a / d)=1 \mathrm{~s} / \mathrm{d} 2,5$ untuk beban terpusat. Keruntuhan ditandai dengan adanya retak lentur halus vertikal di tengah bentang dan tidak terus menjalar. Hal ini dikarenakan adanya kehilangan lekatan pada perletakan antara tulangan longitudinal dengan beton di sekitarnya. Apabila terus dibebani, keruntuhan diikuti dengan timbulnya retak miring yang lebih curam daripada retak diagonal tarik secara tiba-tiba yang menjalar menuju sumbu netral. Pertemuan retak miring beton tertekan yang menjadi penyebab keruntuhan secara tiba-tiba.

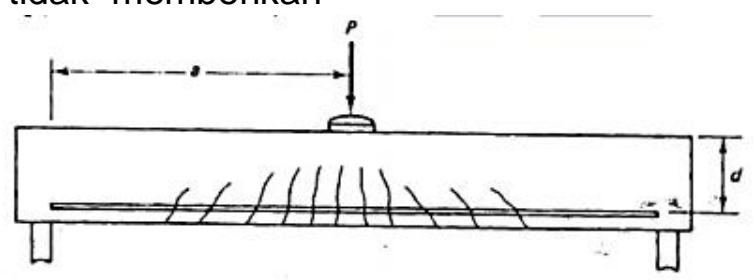

(a)

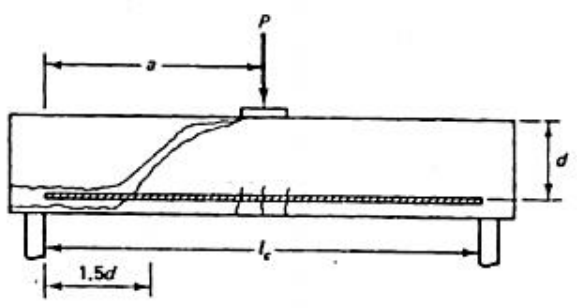

(b)

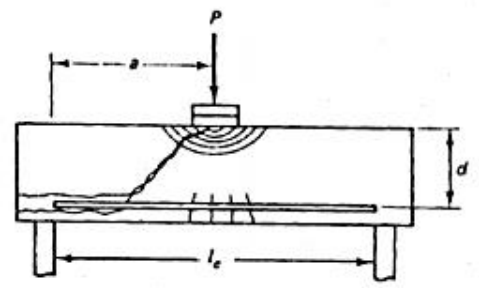

(c)

Gambar 1. Ragam Keruntuhan Sebagai Fungsi dari Kelangsingan Balok: (a) Keruntuhan Lentur; (b) Keruntuhan Tarik Diagonal; (c) Keruntuhan Geser

(Sumber: Nawy, 2010) 
Balok beton bertulang merupakan material yang tidak homogen dan kekuatan yang terjadi di sepanjang bentang merupakan variasi distribusi normal. Oleh karena itu tidak dapat dipastikan apakah retak diagonal dapat terjadi bersama-sama pada kedua ujung perletakan. Selain itu ketidakhomogenan material beton bertulang dapat menyebabkan adanya tumpang tindih antara kegagalan lentur, kegagalan diagonal, dan kegagalan geser baik dari segi rasio bentang geser maupun tingginya.

Tabel 1. Pengaruh Kelangsingan Balok Terhadap Ragam Keruntuhan

Kategori Balok

Ragam Keruntuhan
Perbandingan bentang geser dengan tinggi sebagai ukuran dari kelangsingan

Beban terpusat

\section{Beban terdistribusi}

\begin{tabular}{llcc} 
& & a/d & Ic/d \\
\hline Langsing & Lentur/ Flexural (F) & $>5.5$ & $>16$ \\
Sedang & Tarik Diagonal/ Diagonal Tension (DT) & $2.5-5.5$ & $11-16 \mathrm{~b}$ \\
Tinggi & Tekan Geser/Shear Compression (SC) & $1-2.5$ & $1-5 \mathrm{~b}$ \\
\hline
\end{tabular}

Kuat geser didasarkan pada tegangan geser rata-rata pada penampang efektif penuh $b_{w}$ dan $d$. Pada komponen struktur

$$
v=\frac{V A \bar{y}}{I b}
$$

tanpa tulangan geser, gaya geser diasumsikan ditahan oleh beton. Pada komponen struktur dengan tulangan geser, porsi kuat geser diasumsikan disumbang oleh beton dan tulangan geser.

Apabila diambil bagian terkecil dari balok diperoleh perilaku geser sebagai berikut:

dengan:

$v$ : tegangan geser

$V$ : gaya geser

$A$ : luas penampang melintang

$\bar{y}$ : jarak titik berat $\mathrm{A}$ ke sumbu netral

$I$ : momen inersia penampang melintang

$b$ : lebar balok

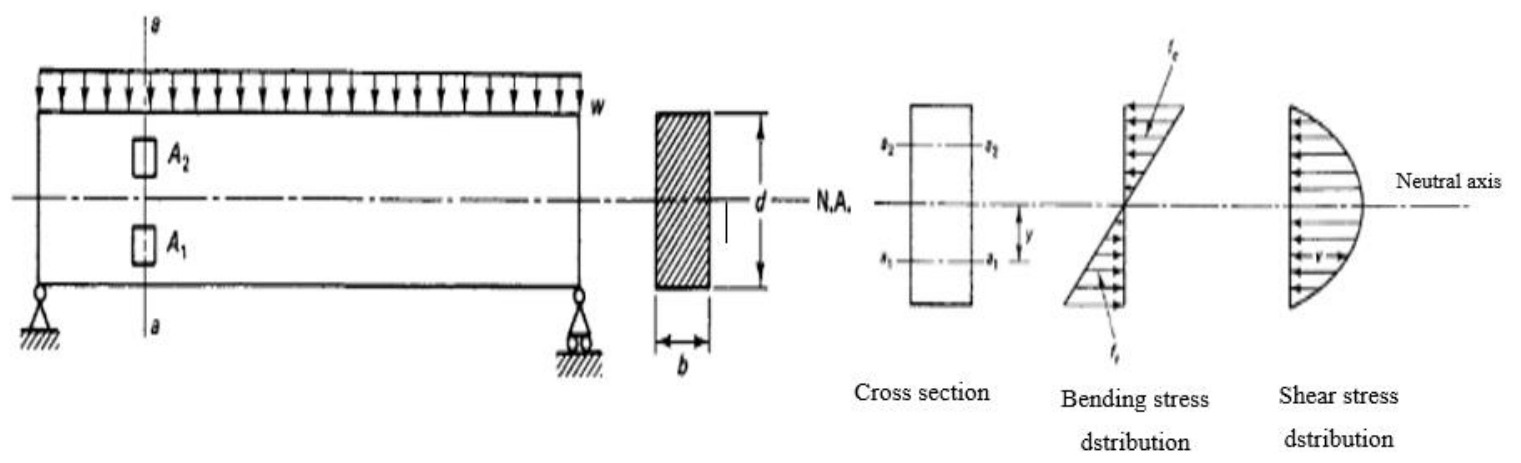

Gambar 2. Distribusi Tegangan Geser Balok

(Sumber: Nawy, 2010)

Tegangan tarik utama bekerja pada bidang yang hampir $45^{\circ}$ terhadap sumbu penampang di daerah dekat perletakan. Karena kecilnya kekuatan tarik beton, maka timbul retak diagonal sepanjang bidang yang tegak lurus bidang tegangan utama yang disebut retak tarik diagonal. 


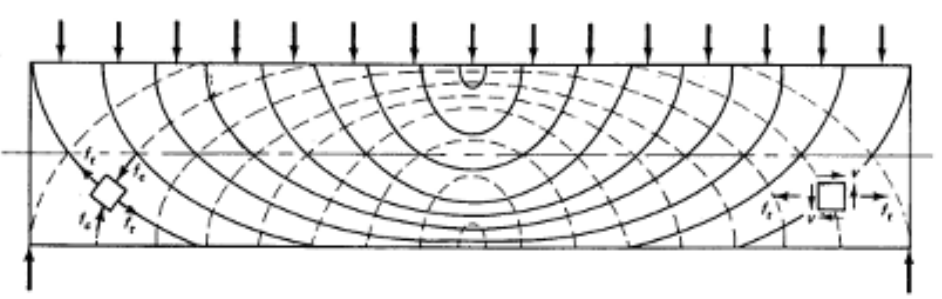

Gambar 3. Trayektori Prinsip Tegangan Geser pada Balok

(Sumber: Nawy, 2008)

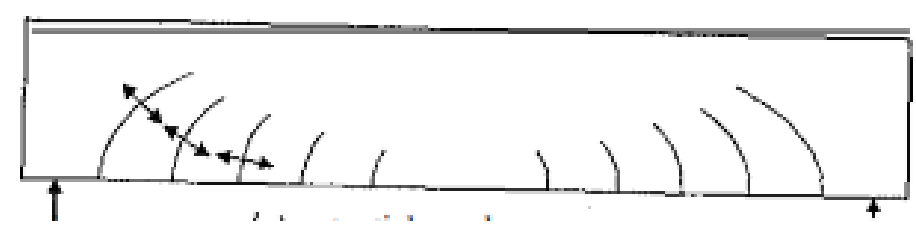

Gambar 4. Potensi Pola Retak

(Sumber: Pillai, 2009)

Menurut peraturan SNI 2847:2013, pasal 11.1, perencanaan penampang terhadap geser harus didasarkan pada:

$$
\varnothing V_{n} \geq V_{u}
$$

$V_{u}$ merupakan gaya geser berfaktor pada penampang yang ditinjau. Faktor reduksi kekuatan $\varnothing$ untuk geser diambil sebesar 0,75 .

Kekuatan geser nominal $V_{n}$ dapat dihitung dengan persamaan:

$V_{n}=V_{c}+V_{s}$

dengan:

$V_{c}=$ kekuatan geser nominal yang disumbang oleh beton

$V_{s}=$ kekuatan geser nominal yang disumbang oleh tulangan geser
Kekuatan geser beton $V_{c}$ untuk struktur non prategang hanya dibebani geser dan lentur saja, menurut SNI 2847:2013 pasal 11.2.1.1 adalah sebagai berikut:

$$
V_{c}=0,17 \lambda \sqrt{f_{c}{ }^{\prime} b_{w} d}
$$

Pengkajian pengaruh kekuatan tekan $\left(f_{c}{ }^{\prime}\right)$ terhadap kekuatan geser beton telah menghasilkan penemuan yang kontradiktif. Perbedaan penemuan tersebut dikemukakan oleh Rebeiz (2001:467) bahwa menurut Clark kapasitas geser balok akan memiliki hubungan yang sejajar dengan kekuatan beton dengan persyaratan seluruh faktor lain yang mendukung memiliki nilai yang sama, sedangkan Kani menyatakan bahwa kekuatan tekan beton bukan merupakan variabel yang penting dalam menghitung kekuatan geser balok beton tanpa tulangan.

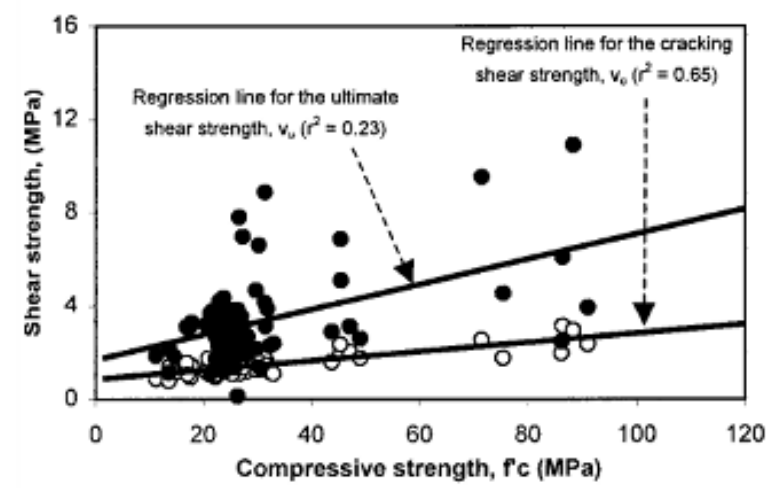

O Cracking strength, $\mathrm{v}_{\mathrm{c}}(\mathrm{Mpa})$

- Ultimate shear strength, $\mathrm{v}_{\mathrm{u}}(\mathrm{Mpa})$

Gambar 5. Efek Kekuatan Tekan Terhadap Kekuatan Geser Retak dan Ultimit

(Sumber: Rebeiz, 2001) 
Meskipun penelitian terdahulu telah banyak melakukan pengkajian mengenai kekuatan geser, namun di Indonesia variabel utama yang mendukung terjadinya kekuatan geser belum dapat dijelaskan dengan rinci melalui literatur yang biasa menjadi rujukan. Menurut Nawy, 2010 perilaku keruntuhan dapat dapat dibagi menjadi tiga tahapan, yaitu: (1) elastic penuh (belum retak); (2) tahapan mulai retak; (3) tahapan plastis (leleh pada baja atau beton pecah). Selama ini masih sangat sedikit literatur yang digunakan di Indonesia yang melalukan pengkajian mengenai kekuatan geser retak $\left(V_{c r}\right)$ dan kekuatan geser ultimate $\left(V_{u}\right)$. Perbedaan $\left(V_{c r}\right)$ dan $\left(V_{u}\right)$ menjadi sangat penting dikarenakan efek dari variabel utama kedua kekuatan geser sangat berbeda. Pada kekuatan geser retak $\left(V_{c r}\right)$ pembentukan retak miring pertama sepenuhnya berkembang menuju ke bangian tengah bentang, sedangkan kekuatan geser ultimate $\left(V_{u}\right)$ merupakan kegagalan kombinasi yang diakibatkan oleh fenomena tegangan geser dan diagonal.

Kekuatan beton tidak lepas dari proses perawatan beton. Proses perawatan beton

\section{METODE}

Metode eksperimental yang digunakan dalam karya ini memiliki tujuan untuk menyelidiki tingkat hubungan antara kuat tekan beton dengan kapasitas geser pada balok beton bertulang dan tanpa tulangan pada kondisi basah dan kering. Pengkajian yang dilakukan di Laboratorium Bahan Bangunan dan Laboratorium Struktur Fakultas Teknik Universitas Gadjah Mada Yogyakarta ini dilakukan secara bertahap yang meliputi pengujian material pembentuk beton, perancangan campuran beton, pengujian kuat tekan beton pada kondisi basah dan kering, dan pengujian kuat geser balok kondisi basah dan kering. Kondisi basah merupakan kondisi benda uji yang direndam hingga benda uji siap untuk dilakukan pengujian, sedangkan kondisi kering merupakan kering permukaan yang berupa perendaman berperan penting dalam proses membantu hidrasi semen, mengontrol temperatur dan kadar kelembaban pada beton sehingga berada dalam kondisi jenuh air, (Neville, 2011). Beton yang berada dalam kondisi basah dan kering akan memiliki kekuatan yang berbeda. Penelitian yang dilakukan oleh Soroka, 1994 telah membuktikan bahwa beton dengan kondisi kering akan memiliki kekuatan yang lebih tinggi daripada beton dengan kondisi basah. Pada konstruksi bangunan air, material beton yang digunakan sebagian besar berada dalam kondisi basah, sehingga perlu dilakukan pengkajian mengenai perbedaan pengaruh antara kedua peluang kondisi yang dialami oleh material beton.

Pengkajian mengenai korelasi kuat tekan terhadap kapasitas geser balok beton dengan variasi perawatan ini dilakukan untuk mengetahui seberapa besar pengaruh antara kedua variabel tersebut baik pada beton tanpa tulangan maupun pada beton bertulang. Pengkajian dilakukan pada kekuatan geser pada saat retak $\left(V_{c r}\right)$ dan kekuatan geser ultimate $\left(V_{u}\right)$.

diperoleh dengan menganginkan benda uji pada suhu ruang dengan lama perbandingan antara lama perendaman dalam air dan waktu benda uji dianginanginkan pada suhu ruang sebesar 3:1.

Benda uji beton yang digunakan sebagai data kuat tekan beton menggunakan silinder beton dengan ukuran diameter 150 $\mathrm{mm}$ dan tinggi $300 \mathrm{~mm}$. Kapasitas geser diperoleh dari benda uji balok beton bertulang berukuran px/xt adalah 1000x200x400 $\mathrm{mm}^{3}$ dengan detail dimensi disajikan pada Gambar 6. Keruntuhan geser yang diinginkan didesain dengan bentuk balok tinggi yang memiliki rasio bentang geser dengan tinggi efektif penampang $(a / d)$ adalah 1,1 . 


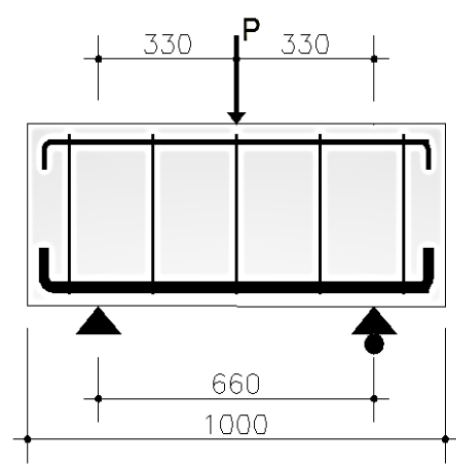

(a)

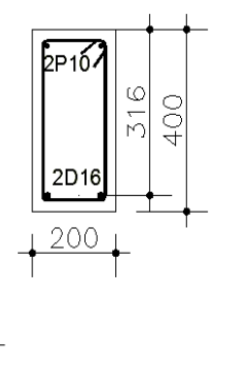

Gambar 6. Dimensi Benda Uji: (a) Balok Beton Bertulang; (b) Balok Beton Tanpa Tulangan

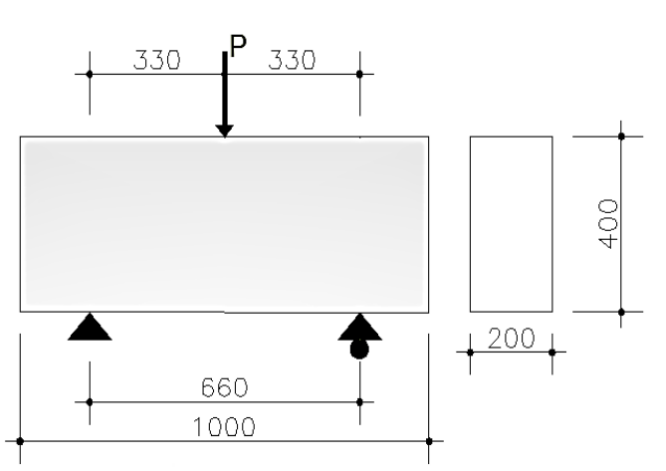

(b)
Bahan yang digunakan dalam pembuatan benda uji menggunakan split Celereng yang diperoleh dari stone cluster PT.HARMAK dengan gradasi butir 10-20 mm. Agregat halus yang digunakan berasal dari Sungai Progo, Yogyakarta dan semen PPC (Pozzoland Portland Cement) Gresik. Mutu baja yang digunakan sebagai tulangan balok sebesar fy = $240 \mathrm{MPa}$ untuk tulangan polos dan $f y=390 \mathrm{MPa}$ untuk tulangan ulir. $f^{\prime} c=25 \mathrm{MPa}$ dan FAS (Faktor Air Semen) sebesar 0,5. Perancangan campuran beton mengacu pada SNI 03:2834:2000. Pengujian kuat tekan beton dilakukan pada umur beton 28 hari dan 90 hari dengan pedoman SNI 1974:2011. Pengujian kuat tekan beton menggunakan mesin tekan UTM dan dial regangan beton. Pengujian kapasitas geser dilakukan pada umur beton 90 hari dengan setting-up pengujian pada.

Beton yang digunakan sebagai benda uji direncanakan dengan kuat tekan sebesar

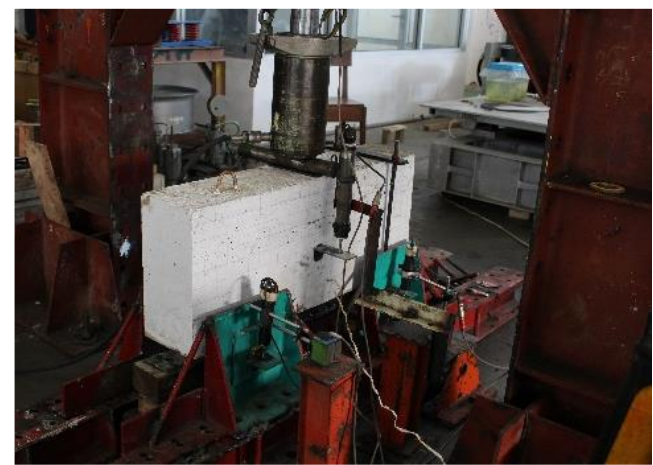

(a)

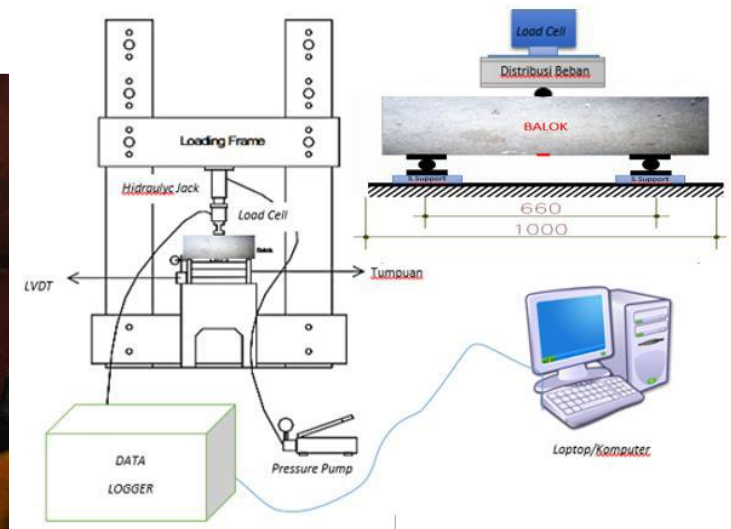

(b)

Gambar 7. Setting-up Pengujian Geser

Tabel 2. Jumlah Sampel Benda Uji

\begin{tabular}{|c|c|c|c|}
\hline \multirow{2}{*}{ Kode } & \multicolumn{2}{|c|}{ Jumlah Benda Uji } & \multirow[t]{2}{*}{$\begin{array}{c}\text { Umur Rencana Beton } \\
\text { (Hari) }\end{array}$} \\
\hline & Silinder & Balok & \\
\hline SB-B & 3 & - & 28 \\
\hline SB-K & 3 & - & 28 \\
\hline SB-B & 3 & - & 90 \\
\hline SB-K & 3 & - & 90 \\
\hline BB-BT & - & 3 & 90 \\
\hline BK-BT & - & 3 & 90 \\
\hline BB-BTT & - & 3 & 90 \\
\hline BK-BTT & - & 3 & 90 \\
\hline
\end{tabular}


Keterangan:

SB-B : Silinder beton kondisi basah

SB-K : Silinder beton kondisi kering

BB-BT : Balok beton bertulang kondisi basah

BK-BT : Balok beton bertulang kondisi kering

BB-BTT: Balok beton tanpa tulangan kondisi basah

BK-BTT: Balok beton tanpa tulangan kondisi kering
Jumlah benda uji yang dibutuhkan dalam pengkajian ini dapat dilihat pada Tabel 2 . Variabel bebas dalam kajian ini berupa variasi kondisi benda uji yang terdiri dari kondisi basah kering serta beton dengan tulangan dan tanpa tulangan, sedangkan variabel yang menjadi pengaruh dari variabel bebas adalah kuat tekan silinder beton. Variabel yang dijadikan kontrol dalam kajian ini adalah material pembentuk beton, FAS, rasio bentang geser $a / d$, dan umur beton.

Alur kerja dalam kajian ini disampaikan pada Gambar 8.

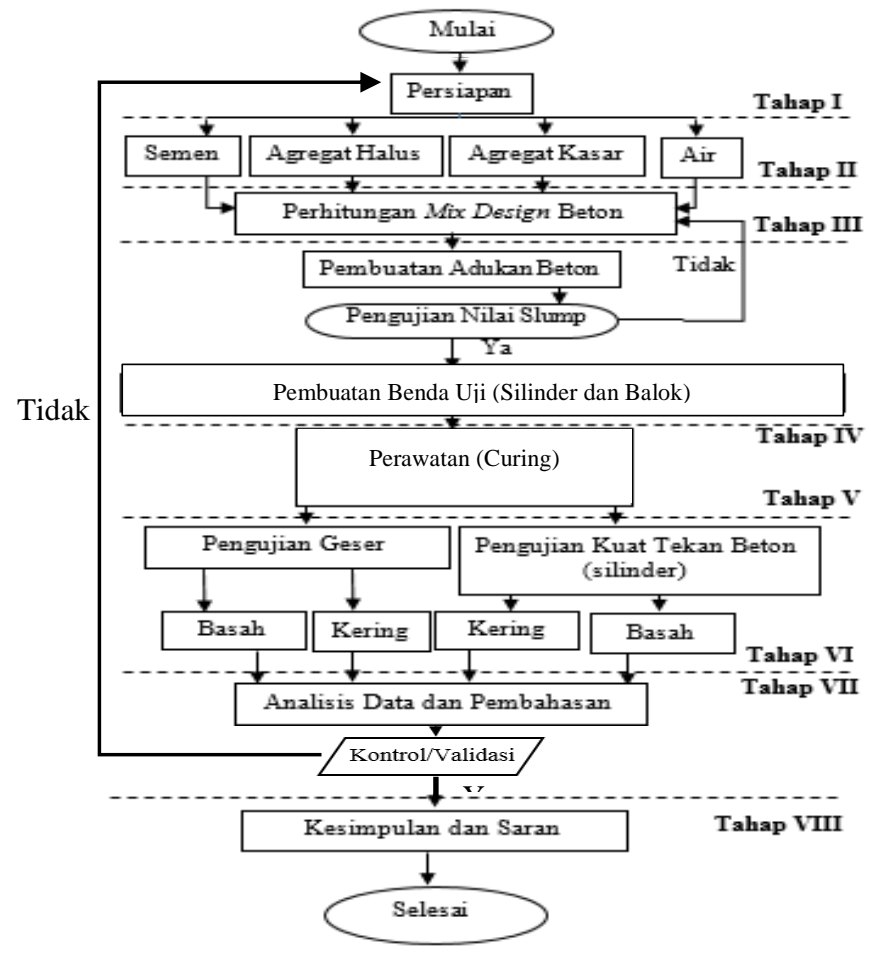

Gambar 8. Flowchart Pengujian

\section{HASIL DAN PEMBAHASAN}

Pemeriksaan bahan dasar penyusun beton dilaksanakan sebelum pembuatan benda uji, dengan pemeriksaan meliputi pengujian agregat halus, agregat kasar, semen dan air yang dilakukan di Laboratorium Bahan
Bangunan Fakultas Teknik Universitas Gadjah Mada, Yogyakarta. Data pengujian agregat halus dan kasar disajikan dalam Tabel 3 dan Tabel 4.

Tabel 3. Tabel Pengujian Agregat Halus

\begin{tabular}{lccc}
\hline \multicolumn{1}{c}{ Jenis Pengujian } & Hasil Pengujian & Standar & Kesimpulan \\
\hline Kandungan Lumpur & $2,208 \%$ & $<5 \%$ & Memenuhi syarat \\
Bulk Specific Gravity & $2,6885 \mathrm{gr} / \mathrm{cm}^{3}$ & $>2,5 \mathrm{gr} / \mathrm{cm}^{3}$ & Memenuhi syarat \\
Bulk Specific SSD & $2,7645 \mathrm{gr} / \mathrm{cm}^{3}$ & $>2,5 \mathrm{gr} / \mathrm{cm}^{3}$ & Memenuhi syarat \\
Apparent Specific Gravity & $2,7265 \mathrm{gr} / \mathrm{cm}^{3}$ & $>2,5 \mathrm{gr} / \mathrm{cm}^{3}$ & Memenuhi syarat \\
\hline
\end{tabular}


Korelasi Kuat Tekan ... (Elviana/ hal 10-22)

Tabel 3. Tabel Pengujian Agregat Halus

\begin{tabular}{lccc}
\hline \multicolumn{1}{c}{ Jenis Pengujian } & Hasil Pengujian & Standar & Kesimpulan \\
\hline Absorbtion & $2,828 \%$ & $<3 \%$ & Memenuhi syarat \\
Modulus Halus Butir & 2,67 & $1,5 \leq \mathrm{MHB} \leq 3,8$ & Memenuhi syarat \\
\hline
\end{tabular}

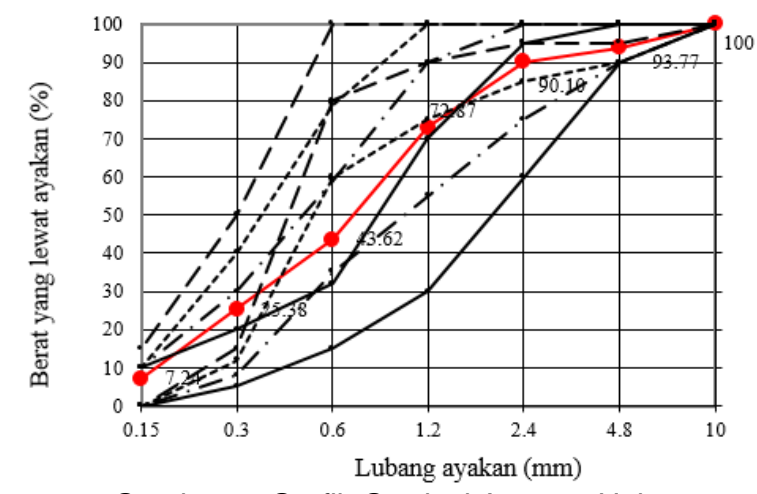

Gambar 9. Grafik Gradasi Agregat Halus

Tabel 4. Tabel Pengujian Agregat Kasar

\begin{tabular}{lccc}
\hline \multicolumn{1}{c}{ Jenis Pengujian } & Hasil Pengujian & Standar & Kesimpulan \\
\hline Abrasi Los Angeles & $16,41 \%$ & $<40 \%$ & Memenuhi syarat \\
Abrasi Rudellof & $8,14 \%$ & $<24 \%$ & Memenuhi syarat \\
Bulk Specific Gravity & $2,5335 \mathrm{gr} / \mathrm{cm}^{3}$ & $>2,5 \mathrm{gr} / \mathrm{cm}^{3}$ & Memenuhi syarat \\
Bulk Specific SSD & $2,5535 \mathrm{gr} / \mathrm{cm}^{3}$ & $>2,5 \mathrm{gr} / \mathrm{cm}^{3}$ & Memenuhi syarat \\
Apparent Specific Gravity & $2,5435 \mathrm{gr} / \mathrm{cm}^{3}$ & $>2,5 \mathrm{gr} / \mathrm{cm}^{3}$ & Memenuhi syarat \\
Absorbtion & $0,802 \%$ & $<3 \%$ & Memenuhi syarat \\
\hline
\end{tabular}

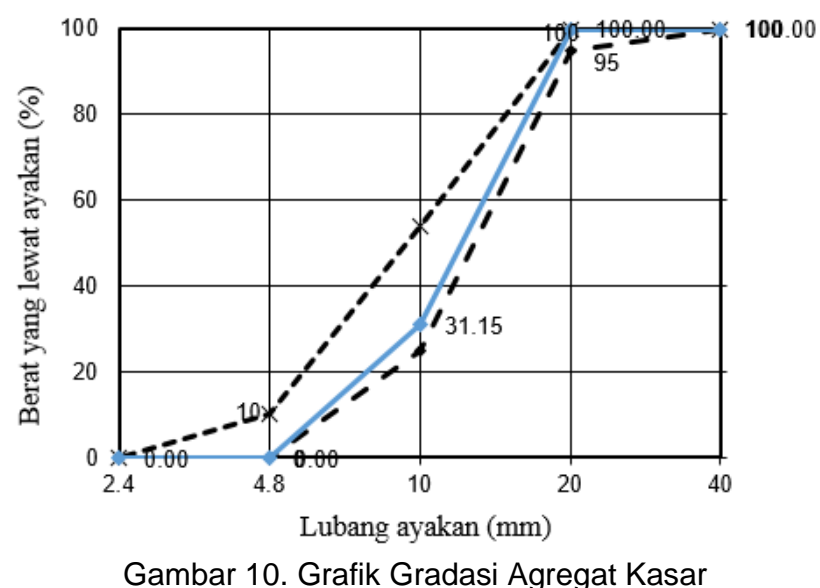

Berdasarkan data yang diperoleh dari hasil pengujian dapat disimpulkan bahwa agregat halus memenuhi syarat ASTM-31 dan berada dalam zona II (agak kasar). Selain itu agregat kasar yang digunakan dalam pembuatan benda uji memenuhi syarat batas ASTM C-33 dan masuk ke dalam jenis batuan andesit.
Pengujian kuat tekan beton dilakukan dengan tujuan untuk mengetahui perbandingan kekuatan beton pada saat diuji pada kondisi basah dan kering. Selama pengujian kuat tekan berlangsung dilakukan pengamatan regangan yang terjadi untuk mengetahui besar modulus elastisitas beton. Pengujian kuat tekan dilakukan pada saat beton pada umur 28 hari dan 90 hari 
Korelasi Kuat Tekan ... (Elviana/ hal 10-22)

dengan hasil yang disajikan dalam Tabel 5 dan Tabel 6.

Dengan adanya keterbatasan alat maka benda uji dilakukan pengujian geser pada umur beton 150 hari, sehingga kekuatan tekan beton diperoleh dengan melakukan pengujian core drill. Data yang diperoleh dapat dilihat pada Tabel 7 dan kuat tekan beton setelah terkoreksi disajikan pada Tabel 8.

Tabel 5. Tabel Hasil Pengujian Kuat Tekan Beton Umur 28 Hari

\begin{tabular}{|c|c|c|c|c|c|c|c|c|c|}
\hline Nomor & Kode & $\begin{array}{l}\text { Umur } \\
\text { Test }\end{array}$ & $\begin{array}{c}\text { Beban } \\
\text { (P) }\end{array}$ & $\begin{array}{l}\text { Kuat } \\
\text { Tekan } \\
\text { Beton }\end{array}$ & $\begin{array}{c}\text { Kuat } \\
\text { Tekan } \\
\text { Beton } \\
\text { Rata- } \\
\text { rata }\end{array}$ & $\begin{array}{l}\text { Modulus } \\
\text { Elastisitas }\end{array}$ & $\begin{array}{c}\text { Modulus } \\
\text { Elastisitas } \\
\text { Rata-rata }\end{array}$ & Tinggi & Diameter \\
\hline & & (Hari) & $(\mathrm{kN})$ & (MPa) & (MPa) & & & $(\mathrm{cm})$ & $(\mathrm{cm})$ \\
\hline 1 & SB-K1 & 28 & 510 & 27,24 & & 24529,61 & & 30,40 & 15,44 \\
\hline 2 & SB-K2 & 28 & 490 & 27,43 & 28,41 & 24617,82 & 25042,87 & 30,00 & 15,08 \\
\hline 3 & SB-K3 & 28 & 540 & 30,56 & & 25981,16 & & 30,30 & 15,00 \\
\hline 4 & SB-B1 & 28 & 375 & 21,22 & & 21650,97 & & 30,00 & 15,00 \\
\hline 5 & SB-B2 & 28 & 450 & 25,40 & 23,19 & 23685,86 & 22618,51 & 30,00 & 15,02 \\
\hline 6 & SB-B3 & 28 & 410 & 22,96 & & 22518,71 & & 29,80 & 15,08 \\
\hline
\end{tabular}

Tabel 6. Tabel Hasil Pengujian Kuat Tekan Beton Umur 90 Hari

\begin{tabular}{|c|c|c|c|c|c|c|c|c|c|}
\hline Nomor & Kode & $\begin{array}{c}\text { Umur } \\
\text { Test }\end{array}$ & $\begin{array}{c}\text { Beban } \\
\text { (P) }\end{array}$ & $\begin{array}{l}\text { Kuat } \\
\text { Tekan } \\
\text { Beton }\end{array}$ & $\begin{array}{c}\text { Kuat } \\
\text { Tekan } \\
\text { Beton } \\
\text { Rata- } \\
\text { rata }\end{array}$ & $\begin{array}{l}\text { Modulus } \\
\text { Elastisitas }\end{array}$ & $\begin{array}{c}\text { Modulus } \\
\text { Elastisitas } \\
\text { Rata-rata }\end{array}$ & Tinggi & Diameter \\
\hline & & (Hari) & $(\mathrm{kN})$ & (MPa) & (MPa) & & & $(\mathrm{cm})$ & $(\mathrm{cm})$ \\
\hline 1 & SB-K1 & 90 & 560 & 31,15 & & 26230,59 & & 30,17 & 15,13 \\
\hline 2 & SB-K2 & 90 & 550 & 31,12 & 30,19 & 26220,62 & 25817,20 & 30,26 & 15,00 \\
\hline 3 & SB-K3 & 90 & 500 & 28,29 & & 25000,38 & & 29,85 & 15,00 \\
\hline 4 & SB-B1 & 90 & 510 & 28,86 & & 25249,15 & & 30,43 & 15,00 \\
\hline 5 & SB-B2 & 90 & 435 & 24,65 & 27,27 & 23334,36 & 24527,54 & 30,45 & 14,99 \\
\hline 6 & SB-B3 & 90 & 490 & 28,29 & & 24999,11 & & 29,97 & 14,85 \\
\hline
\end{tabular}

Tabel 7. Tabel Kuat Tekan Beton Umur 150 Hari

\begin{tabular}{cccccccccc} 
Nomor & Kode & $\begin{array}{c}\text { Umur } \\
\text { Test }\end{array}$ & $\begin{array}{c}\text { Beban } \\
\mathbf{( P )}\end{array}$ & $\begin{array}{c}\text { Kuat } \\
\text { Tekan } \\
\text { Beton }\end{array}$ & $\begin{array}{c}\text { Rata- } \\
\text { rata } \\
\text { Kuat } \\
\text { Tekan }\end{array}$ & $\begin{array}{c}\text { Modulus } \\
\text { Elastisitas }\end{array}$ & $\begin{array}{c}\text { Modulus } \\
\text { Elastisitas } \\
\text { Rata-rata }\end{array}$ & Tinggi & Diameter \\
& & & & & & & & cm & cm \\
\hline 1 & SB-K1 & 150 & 210 & 30,07 & & 25772,16 & & 18,70 & 9,43 \\
2 & SB-K2 & 150 & 220 & 31,43 & 31,00 & 26350,71 & 26167,17 & 18,76 & 9,44 \\
3 & SB-K3 & 150 & 220 & 31,50 & & 26378,65 & & 17,65 & 9,43 \\
4 & SB-B1 & 150 & 190 & 27,20 & & 24514,22 & & 18,75 & 9,43 \\
5 & SB-B2 & 150 & 190 & 27,20 & 28,16 & 24514,22 & 24933,53 & 18,73 & 9,43 \\
6 & SB-B3 & 150 & 210 & 30,07 & & 25772,16 & & 19,00 & 9,43 \\
\hline
\end{tabular}


Tabel 8. Tabel Kuat Tekan Beton Umur 150 Hari Setelah Terkoreksi

\begin{tabular}{cccccccc} 
Nomor & Kode & $\begin{array}{c}\text { Umur } \\
\text { Test }\end{array}$ & $\begin{array}{c}\text { Beban } \\
\mathbf{( P )}\end{array}$ & $\begin{array}{c}\text { Kuat } \\
\text { Tekan } \\
\text { Beton }\end{array}$ & $\begin{array}{c}\text { Kuat } \\
\text { Tekan } \\
\text { Terkoreksi }\end{array}$ & $\begin{array}{c}\text { Rata-rata } \\
\text { Kuat Tekan }\end{array}$ & $\begin{array}{c}\text { Rata-rata } \\
\text { Kuat Tekan } \\
\text { Terkoreksi }\end{array}$ \\
\hline 1 & SB-K1 & 150 & 210 & 30,07 & 29,47 & & (MPa) \\
\hline 2 & SB-K2 & 150 & 220 & 31,43 & 30,80 & 31,00 & 30,38 \\
3 & SB-K3 & 150 & 220 & 31,50 & 30,87 & & 27,60 \\
4 & SB-B1 & 150 & 190 & 27,20 & 26,66 & & \\
5 & SB-B2 & 150 & 190 & 27,20 & 26,66 & 28,16 & \\
\hline
\end{tabular}

Pengujian geser dilakukan pada benda uji balok dengan menggunakan tulangan untuk mendapatkan nilai $V_{c r}$ dan $V_{u}$ serta balok tanpa tulangan untuk mendapatkan

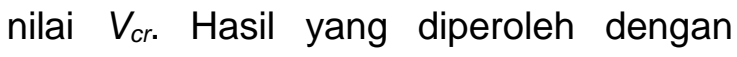
beban terpusat di tengah bentang dapat dilihat pada Tabel 9 dan Tabel 10.

Tabel 9. Tabel Kekuatan Geser Balok Beton Bertulang Kondisi Basah dan Kering

\begin{tabular}{|c|c|c|c|c|c|c|c|}
\hline Kode & $\begin{array}{c}f^{\prime}{ }_{c} \\
(\mathrm{MPa})\end{array}$ & $\begin{array}{c}V_{u} \\
(\mathrm{kN})\end{array}$ & $\begin{array}{c}\text { Rata-rata } \\
V_{u} \\
(\mathrm{kN}) \\
\end{array}$ & $\begin{array}{r}V_{c r} \\
(\mathbf{k N})\end{array}$ & $\begin{array}{c}\text { Rata-rata } \\
V_{c r} \\
(\mathrm{kN}) \\
\end{array}$ & $V_{u} / V_{c r}$ & $\begin{array}{c}\text { Rata-rata } \\
V_{u l t} / V_{c r}\end{array}$ \\
\hline BK-BT1 & 29,47 & 465,4 & \multirow{2}{*}{471,60} & 231,1 & \multirow{2}{*}{229,10} & 2,01 & \multirow{2}{*}{2,06} \\
\hline BK-BT2 & 30,80 & 492,7 & & 233,2 & & 2,11 & \\
\hline BK-BT3 & 30,87 & 456,7 & \multirow{4}{*}{422,30} & 223,0 & \multirow{4}{*}{180,77} & 2,05 & \multirow{4}{*}{2,37} \\
\hline BB-BT1 & 26,66 & 402,9 & & 188,8 & & 2,13 & \\
\hline BB-BT2 & 26,66 & 444,0 & & 157,2 & & 2,82 & \\
\hline BВ-BT3 & 29,47 & 420,0 & & 196,3 & & 2,14 & \\
\hline
\end{tabular}

Tabel 10. Tabel Kekuatan Geser Balok Beton Tanpa Tulangan Kondisi Basah dan Kering

\begin{tabular}{cccc}
\hline Kode & $\begin{array}{c}\boldsymbol{f}^{\prime} \boldsymbol{c}^{\prime} \\
(\mathbf{M P a})\end{array}$ & $\begin{array}{c}\boldsymbol{V}_{\boldsymbol{c r}} \\
(\mathbf{k N})\end{array}$ & $\begin{array}{c}\text { Rata-rata } \\
\boldsymbol{V}_{\boldsymbol{c r}}\end{array}$ \\
\hline BK-BTT1 & 29,47 & 143,10 & 159,23 \\
BK-BTT2 & 30,80 & 194,70 & \\
BK-BTT3 & 30,87 & 139,90 & 200,83 \\
BB-BTT1 & 26,66 & 218,70 & \\
BB-BTT2 & 26,66 & 191,80 & 192,00 \\
BB-BTT3 & 29,47 & & \\
\hline
\end{tabular}

Pendalaman konsep yang telah dilakukan oleh peneliti terdahulu yaitu Rebeiz, dkk (2001) memperoleh hasil bahwa variabel kuat tekan $\left(f_{c}^{\prime}\right)$ memberikan pengaruh terhadap besarnya gaya geser ultimate $\left(V_{u}\right)$ dan gaya geser crack $\left(V_{c r}\right)$ pada rasio bentang geser $a / d<2,5$. Berdasarkan data yang diperoleh dari hasil pengujian pada benda uji dengan rasio bentang geser 1,1 seperti yang telah disajikan pada Tabel 5 hingga Tabel 10 memperlihatkan bahwa semakin tinggi besar kuat tekan $\left(f_{c}{ }^{\prime}\right)$ akan memberikan pengaruh terhadap semakin besar pula nilai gaya geser ultimate $\left(V_{u}\right)$ dan gaya geser crack $\left(V_{c r}\right)$ untuk beton dengan menggunakan tulangan. Hal 
tersebut disebabkan oleh adanya pengaruh aksi lengkung yang memiliki hubungan erat dengan kekuatan tekan beton. Pembebanan pada balok yang relatif pendek ditransfer langsung ke tumpuan melalui aksi lengkung, sehingga memungkinkan tambahan beban ditahan di luar pembentukan retak diagonal utama. Salah satu faktor utama yang mempengaruhi aksi lengkung ini adalah kekuatan yang berkaitan dengan kekuatan tekan beton. Namun demikian, terdapat hasil yang cukup menarik pada balok tanpa tulangan, dikarenakan hasil pengujian menunjukkan bahwa semakin tinggi nilai kuat tekan $\left(f_{c}{ }^{\prime}\right)$, kapasitas gaya geser beton $\left(V_{c r}\right)$ yang diperoleh semakin mengecil.

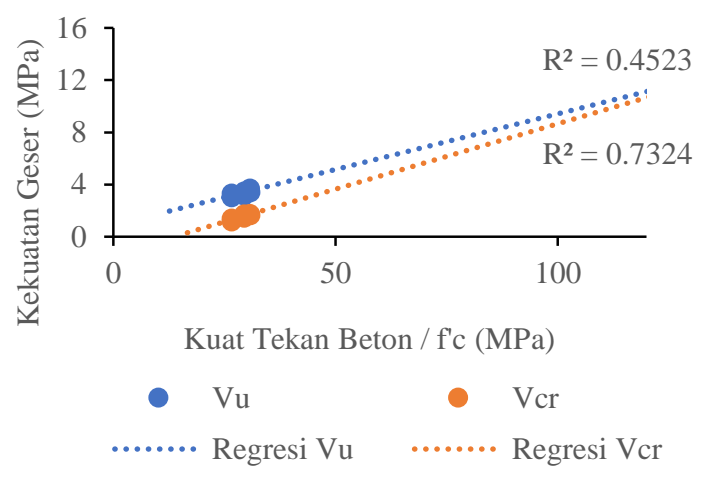

Gambar 11. Grafik Hubungan Efek Kekuatan Tekan Terhadap Kekuatan Geser Retak dan Ultimit Balok Beton Bertulang dengan Rasio Bentang Geser 1,1

Berdasarkan data yang diperoleh selama pengujian berlangsung, dapat diambil grafik hubungan antara efek kekuatan tekan terhadap kekuatan geser retak dan ultimit seperti pada Gambar 11. Grafik yang diperoleh dari data hasil pengujian memiliki tren yang tidak jauh berbeda dengan grafik hubungan antara efek kekuatan tekan terhadap kekuatan geser retak dan ultimit yang telah dipaparkan oleh Rebeiz, 2001. Grafik tersebut menunjukkan bahwa kuat tekan beton bertulang berkolerasi lebih baik terhadap kekuatan geser beton kondisi retak $\left(V_{c r}\right)$ daripada korelasi terhadap kekuatan beton ultimit $\left(V_{u}\right)$. Hal ini dapat dilihat dari koefisien penentuan $\mathrm{R}^{2}$ untuk regresi kekuatan geser beton kondisi retak $\left(V_{c r}\right)$ memiliki nilai yang lebih besar dari kekuatan beton ultimit $\left(V_{u}\right)$. Hubungan antara kuat tekan terhadap kekuatan geser pada kondisi ultimit yang mampu ditahan pada balok beton bertulang berkisar $1 / 8$ dari kekuatan tekan yang dihasilkan, sedangkan

\section{SIMPULAN}

Besarnya kekuatan tekan memberikan penggaruh terhadap kekuatan geser balok beton bertulang yang memiliki rasio bentang geser a/d adalah 1,1. Setelah dilakukan untuk kekuatan geser pada saat retak berkisar 1/17 dari kekuatan tekan yang dihasilkan.

Kekuatan tekan yang dihasilkan pada kondisi basah memiliki nilai yang lebih rendah daripada kekuatan tekan pada kondisi kering pada umur beton 28 hari, 90 hari, dan 150 hari secara berturut-turut adalah 10,64\%; 10;72\%; dan 10,09\%. Penurunan kekuatan yang dihasilkan pada kuat tekan beton juga memberikan pengaruh terhadap kekuatan geser balok beton bertulang yang relatif sama yaitu sebesar $11,67 \%$. Penurunan yang terjadi masih masuk dalam batas toleransi kesesuaian dengan penelitian yang telah dilakukan Soroka, 1994. Soroka memperoleh hasil bahwa kekuatan beton pada kondisi kering lebih baik sebesar 13\% pada umur beton 90 hari dan $9 \%$ pada umur beton 28 hari.

peninjauan terhadap perilaku kekuatan beton pada saat retak $\left(V_{c r}\right)$ dan kekuatan beton ultimit $\left(V_{u}\right)$ diperoleh hasil bahwa kuat tekan beton memiki tingkat korelasi yang 
lebih tinggi terhadap kekuatan beton pada saat retak $\left(V_{c r}\right)$.

Korelasi kekuatan tekan dan kekuatan geser ini berlaku pada kondisi beton dengan variabel lain yang sama. Variabel lain yang dimaksud adalah rasio bentang geser $a / d$, material pembentuk beton, FAS, tipe pembebanan, jenis tumpuan dan umur beton.

\section{DAFTAR RUJUKAN}

ASTM International. Standard Specification for Concrete Aggregates, ASTM C33/C33M-08. United Stated: ASTM International.

ASTM International. Standard Test Method for Density, Relative Density (Specific Gravity), and Absorption of Coarse Aggregate., ASTM C127-01 United Stated: ASTM International.

Badan Standarisasi Nasional Indonesia. 1990. Metode Pengujian Kadar Air Agregat, SNI 03-1971-1990. Jakarta: Badan Standarisasi Nasional Indonesia.

Badan Standarisasi Nasional Indonesia. 2000. Tata Cara Pembuatan Rencana Campuran Beton Normal, SNI 03-2834-2000. Jakarta: Badan Standarisasi Nasional Indonesia.

Badan Standarisasi Nasional Indonesia. 2000. Tata Cara Pembuatan Rencana Campuran Beton Normal, SNI 03-2834-2000. Jakarta: Badan Standarisasi Nasional Indonesia.

Badan Standarisasi Nasional Indonesia. 2008. Cara Uji Berat Isi, Volume Produksi Campuran dan Kadar Udara Beton, SNI 1973:2008. Jakarta: Badan Standarisasi Nasional Indonesia.

Badan Standarisasi Nasional Indonesia. 2008. Cara Uji Berat Jenis dan Penyerapan Air Agregat Halus, SNI 1970:2008. Jakarta: Badan Standarisasi Nasional Indonesia.

Badan Standarisasi Nasional Indonesia. 2008. Cara Uji Berat Jenis dan Penyerapan Air Agregat Kasar SNI
Perawatan beton dengan kondisi beton basah dan kering memiliki pengaruh terhadap kekuatan tekan beton. Oleh karena kekuatan tekan beton memiliki korelasi dengan kekuatan geser, maka secara linier kondisi basah dan kering juga memili pengaruh terhadap kekuatan geser balok. Penurunan yang terjadi akibat beton dalam kondisi basah secara terus menerus adalah berkisar $10-11 \%$ dari beton pada kondisi kering.

1969:2008. Jakarta: Badan Standarisasi Nasional Indonesia.

Badan Standarisasi Nasional Indonesia. 2008. Cara Uji Keausan Agregat dengan Mesin Abrasi Los Angeles, SNI 2417:2008. Jakarta: Badan Standarisasi Nasional Indonesia.

Badan Standarisasi Nasional Indonesia. 2011. Cara Uji Kuat Tekan Beton dengan Benda Uji Silinder, SNI 1974:2011. Jakarta: Badan Standarisasi Nasional Indonesia.

Badan Standarisasi Nasional Indonesia. 2011. Tata Cara Pembuatan dan Perawatan Benda Uji Beton di Laboratorium SNI 2493:2011. Jakarta: Badan Standarisasi Nasional Indonesia.

Badan Standarisasi Nasional Indonesia. 2013. Persyaratan Beton Struktural Untuk Bangunan Gedung, SNI 2847:2013. Jakarta: Badan Standarisasi Nasional Indonesia.

Bhatt, Pran; Thomas J. MacGinley; Ban Seng Choo. 2014. Concrete Design ro Eurocodes Fourth Edition. United States: Bosa Roca.

Mehta, P. K; P.JM. Monteiro. 2006. Concrete . Microstructure, Properties, and Materials Third Edition. New York: McGraw-Hill Book Companies.

Nawy, Edward G. 2008. Concrete Construction Engineering. New York: Taylor \& Francis Group, CRC Press.

Nawy, Edward G. 2010. Prestressed Concrete A Fundamental Approach Fifth Edition. New Jersey: PrenticeHall, Inc. 
Neville, A.M. 2011. Properties of Concrete Fifth Edition. England: Pitman Publishing Limited, Edinburgh Gate.

Park, R; T. Paulay. 1975. Reinforced Concrete Structures. Canada: A Wiley-Interscience Publication.

Pillai, S. Unnikrishna; Devdas Menon. 2009. Reinforced Concrete Design Third Edition. New Delhi: Tata McGrawHill Publishing.

Soroka; H. Baum. 1994. Influence of Specimen Size on Effect of Curing Regime on Concrete Compressive Strength, ASCE. Civil Engineering,6(1):15-22.

Pusjatan Balitbang PU. 1990. Metode Pengujian Tentang Analisis Saringan Agregat Halus dan Kasar, SNI 03-1968-1990. Jakarta: Pusjatan Balitbang PU.

Pustran Balitbang PU. 1997. Metode Pengujian Agregat Halus Atau Pasir yang Mengandung Bahan Plastik dengan Cara Setara Pasir, SNI 034428-1997. Jakarta: Pustran Balitbang PU.

Pustran Balitbang PU. 1998. Metode Pengujian Bobot Isi dan Rongga Udara dalam Agregat, SNI 03-48041998. Jakarta: Pustran Balitbang PU.

Rebeiz, Karim; Javier Fente; Michael A. Frabizzio. 2001. Effect of Variables on Shear Strength of Concrete Beams. ASCE. Journal of Materials in Civil Engineering.

Slowik, Marta. 2014. Shear Failure Mechanism in Concrete Beams. Elsevier. Procedia Materials Science.

Soroka; H. Baum. 1994. Influence of Specimen Size on Effect of Curing Regime on Concrete Compressive Strength, ASCE. Civil Engineering, 6(1):15-22.

Wang, Chu-Kia; Charles G.Salmon. 2006. Reinforced Concrete Design Seventh Edition. New York: Harper \& Row, Publisher.

Zararis, Prodromos; Georrge Ch. Papadakis. 2001. Diagonal Shear Failure and Size Effect in RC Beams Without Web Reinforcement. ASCE. Journal of Structural Engineering. 